\title{
Status of freshwater crayfish (Astacus leptodactylus) in Iran
}

\author{
M. Karimpour( ${ }^{(1)}$, M.M. Harlioğlu(2), Ö. Aksu(3)
}

Received October 25, 2010

Revised March 18, 2011

Accepted April 19, 2011

Key-words:

Astacus leptodactylus, crayfish, distribution, harvest, introduction, Iran

\section{ABSTRACT}

Iranian native crayfish includes one crayfish species, Astacus leptodactylus, with two subspecies, $A$. I. leptodactylus (lives in freshwater) and $A$. I. eichwaldi (lives in the Caspian Sea with 12 ppt salinity). Only A. leptodactylus is commonly distributed in Iranian water resources. Nearly 80 years ago local fishermen started to catch Anzali Lagoon crayfish and sold them to foreigners and embassy employees. The consumption of crayfish in Iran is very low, approximately $1 \mathrm{t}$ annually. The first commercially significant crayfish harvest in Iran was $11.3 \mathrm{t}$ from Anzali Lagoon in 1985. It was carried out by a Turkish company. In 1985, the introduction of $A$. leptodactylus was started into suitable Iranian freshwaters. For example, crayfish from Anzali Lagoon were introduced into Arass water reservoir in 1985. Today, Arass water reservoir is the main resource of crayfish in Iran. There was no further crayfish harvest in Iran until 1993. In that year, a private Iranian company began harvesting the Iranian crayfish and exporting them to European countries. In 1993, $3.2 \mathrm{t}$ of crayfish were exported from Iran. Although there have been fluctuations between years, the export of crayfish in Iran increased remarkably after 1996. The successful results of crayfish introductions gave rise to this increase. In 2003, the export of $A$. leptodactylus from Iran reached the maximum level $(216 \mathrm{t})$. The commercial value of exported crayfish between 2000 and 2009 varied from 1.5-2.5 million US\$ annually and its amount was 106-211.5 t. However, there was a reduction in the export of $A$. leptodactylus from Iran after 2003, to just above $100 \mathrm{t}$. In conclusion, in order to increase crayfish production in Iran, introduction of $A$. leptodactylus into suitable water resources, and management, conservation and monitoring of present crayfish populations should be carried out.

\section{RÉSUMÉ}

\section{Statut de l'écrevisse à pattes grêles (Astacus leptodactylus) en Iran - Revue}

Mots-clés :

Astacus leptodactylus,
Astacus leptodactylus, indigène en Iran, présente deux sous-espèces A. I. leptodactylus (vivant en eau douce) et $A$. I. eichwaldi (vivant dans la mer Caspienne à 12 ppt de salinité). Seule $A$. leptodactylus est présente couramment

(1) Azarbayjan St., Mehrab St. No. 15, 4315756994 Bandar Anzali, Iran, mohammad_karimpour@yahoo.com

(2) Fisheries Faculty, Fırat University, 23119 Elazığ, Turkey, mharlioglu@firat.edu.tr

(3) Fisheries Faculty, Tunceli University, Tunceli, Turkey, onderaksu@tunceli.edu.tr 
écrevisse, distribution, production, Iran dans les ressources aquatiques iraniennes. II y a environ 80 ans que les pêcheurs locaux ont commencé à capturer l'écrevisse dans le lagon Anzali et à les vendre à l'étranger et aux employés d'ambassades. La consommation d'écrevisses en Iran est très basse, approximativement $1 \mathrm{t}$ par an. La première production d'écrevisses en Iran a été de 11,3 t dans le lagon Anzali en 1985. Cela a été réalisé par une compagnie turque. En 1985, l'introduction d'A. leptodactylus a débuté dans les eaux douces iraniennes propices. Par exemple, les écrevisses du lagon Anzali ont été introduites dans le réservoir Arass en 1985. Aujourd'hui le réservoir Arass est la principale source d'écrevisses en Iran. II n'y a pas eu de récolte d'écrevisses en Iran jusqu'en 1993. Cette année-là, une compagnie iranienne privée a démarré la pêche et les a exportées dans les pays européens. En 1993, 3,2 t d'écrevisses ont été exportées d'Iran. En 2003, les exportations d'A. leptodactylus ont atteint un maximum de 216 t. En conclusion, pour augmenter la production d'écrevisses en Iran, l'introduction d'A. leptodactylus dans des milieux propices, la gestion, la conservation et le suivi des populations d'écrevisses pourraient être développés.

\section{INTRODUCTION}

In 1964, it was reported that two species of crayfish were found in the Iranian waters of the Caspian Sea shore, Astacus leptodactylus and Astacus pachypus. A. leptodactylus was found not only in the Caspian Sea up to 5-10 km offshore (Veladykov, 1964) but also in freshwater. The first study on crayfish (Astacus leptodactylus) was carried out by Abassi (1969). The author examined the length frequency in the narrow-clawed crayfish population in Anzali lagoon. A few years later, Butcher (1971) carried out some preliminary research on Anzali lagoon crayfish as well. In 1987, it was stated that there were two subspecies of Astacus in Iran. Astacus leptodactylus leptodactylus lives in the Anzali lagoon and Astacus leptodactylus eichwaldi (Astacus pachypus) lives in the Caspian Sea (Petr, 1987).

The populations of $A$. I. leptodactylus in Anzali Lagoon and in its rivers and outlets are assumed to be the result of natural species distribution. The other populations that exist in Iran are effects of introductions. The list of known introductions in Iran is shown below; the number of introduced specimens and their size is given in parenthesis:

- Arass water reservoir in 1988 (20 000 crayfish, 15-25 g in weight),

- Haft Barm Lake in 2001 (5000 crayfish),

- Izadkhast water reservoir in 2001 and 2002 (7000 crayfish in total, 15-20 g in weight),

- Khamiran water reservoir in 2001 (3500 crayfish),

- Malek Kian water reservoir in 1999 and 2000 (33 750 crayfish),

- Shahid Yaghoobi water reservoir in 2001 (3500 crayfish),

- Yam water reservoir in 2002 (1500 crayfish),

- Shoorabil Lake between 2000 and 2003 (15000 crayfish),

- Khandaghloo Lake in 2000 and 2003.

Figure 1 shows the distribution of crayfish populations in Iran.

\section{CRAYFISH INTRODUCTIONS INTO IRAN}

In Iran, the first crayfish introduction was carried out by the Iranian Fisheries Research Organization from Anzali Lagoon into Arass, which has plenty of benthic organisms, in 1988. 20000 crayfish (15-25 g in weight) were used for stocking. The next project was performed between 1997 and 1998 on the determination of population dynamics and MSY (maximum sustainable yield) by Karimpour and Hosseinpour (1999). The findings of the project revealed that the first crayfish introduction was successful. As a result of this success, the idea of introducing crayfish into freshwater resources increased in Iran. 


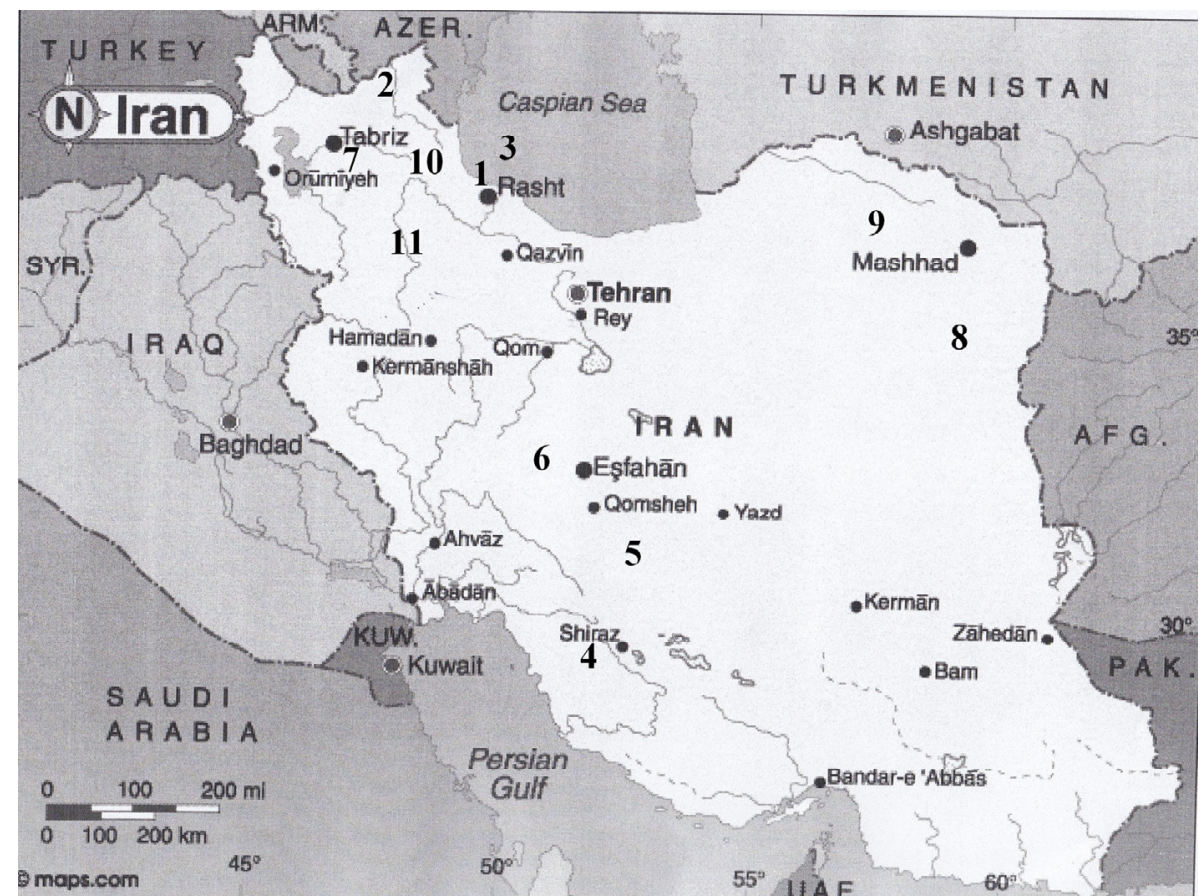

\section{Figure 1}

Distribution of crayfish populations (A. I. leptodactylus and A. I. eichwaldi) in Iran (1: Anzali Lagoon, 2: Arass water reservoir, 3: Caspian Sea, 4: Haft Barm Lake, 5: Izadkhast water reservoir, 6: Khamiran water reservoir, 7: Malek Kian water reservoir, 8: Shahid Yaghoobi water reservoir, 9: Yam water reservoir, 10: Shoorabil Lake, 11: Khandaghloo Lake).

Figure 1

Distribution des populations d'écrevisses (A. I. leptodactylus et A. I. eichwaldi) en Iran.

In 1997, the Iranian Fisheries Organization formed a committee to organize crayfish introductions into suitable freshwater resources. Introductions were carried out in the following ways:

- introducing juvenile (young-of-the-year) crayfish (1-2 g);

- introducing pleopodal egg-bearing females;

- introducing 15-20 g crayfish (1+, 2+ age groups).

In practice, the mortality of juveniles during transportation was high and the costs of young crayfish culture and transportation of cultured juveniles were very expensive. Furthermore, pleopodal eggs of females were very sensitive to mass transportation. For example, some pleopodal eggs deteriorated or separated from the females during transportation. Welloxygenated water was also required in this method.

The use of 15-20 g crayfish for introduction purposes was assumed to be the most effective. The advantage of this method is that it is very efficient, easy and cheap, with transportation of crayfish in polystyrene boxes that guarantee a very low mortality as well. For these reasons, after 1999 15-20 g crayfish were preferred for introductions.

All crayfish introductions have been carried out into 18 water resources of 13 provinces in Iran up to now. Introductions are monitored every year by the Iranian Fisheries Research Organization. Before the introduction of crayfish some abiotic conditions (air and water temperature, dissolved oxygen, $\mathrm{pH}$, total hardness, calcium, total organic matter), and some biotic parameters (plankton and benthic organisms) that have an effect on crayfish life were measured.

The average rate of stock was 60-90 crayfish per hectare, and the sex ratio was: 2 females, 1 male. The minimum surface of each water body was base for the number of introduced crayfish. The results showed that the crayfish acclimatized well in all water bodies. 
The 5 (from all 18) water bodies' surface was less than 20 ha. The results showed the population of crayfish quickly increased; the MSY of these water bodies ( $<20 \mathrm{ha})$ is estimated at about 60 t (Abdolmalaki, 2007; Karimpour, 2009).

Some factors that had a negative impact on the results of the effectiveness of crayfish introductions in Iran are listed below.

\section{DIFFICULTIES IN CRAYFISH INTRODUCTIONS}

1. The natural causes of drought. Approximately $80 \%$ of Iran is located in a dry zone with average annual rainfall of less than $200 \mathrm{~mm}$, and naturally some of the water resources are in the dry zone, such as Izadkhast, Khamiran, Shahid Yaghoobi and Yam reservoirs.

2. The anthropogenic causes of drought. In Iran, the main reason for building reservoirs is irrigation for agricultural areas. In drought years, the water from reservoirs is discharged into agricultural lands. In these circumstances, the crayfish inhabiting the reservoirs go out with off-loading water through canals and finally die in farms. The Iranian Fisheries Organization suggested to the Water Resources Organization to keep a minimum level of water to care for the crayfish stocks, but in some years the Water Resources Organization is under the pressure of farmers to apply this regulation.

3. Non-indigenous fish species introductions. In Iran, common carp (Cyprinus carpio), silver carp (Hypophthalmichthys molitrix), big head carp ( $H$. nobilis) and grass carp (Ctenopharyngodon idella) were also introduced into most reservoirs and lakes in which crayfish were present. Therefore, these fish species are food competitors for crayfish and predators as well. Juvenile crayfish and molted crayfish with soft shells are valuable diet items for these fish.

4. Use of non-selective fishing gears. Some fishermen set their gill-nets illegally in reservoirs and lakes to catch carp. For example, gill-nets are set at the bottom to hide them from patrols. The by-catch of these gill-nets is crayfish. The crayfish captured in the meshes of gill-nets and fishermen cleaning their gill-nets cause crayfish mortality. Unfortunately, this situation is very common in most water resources. A huge amount of crayfish die in this way, especially in the breeding season.

5. Poaching. There are some restricted and protected areas for catching crayfish in all water resources in Iran. However, some crayfish fishermen do not heed this prohibition.

6. Water pollution. Pesticides (herbicides and insecticides) carried by rivers and seasonal floods into water resources sometimes have harmful effects on crayfish stocks. For example, crayfish juvenile mortality caused by pesticides was reported by Ghoolami (2002).

\section{DESCRIPTIONS OF IRANIAN CRAYFISH POPULATIONS}

The geographical information (flatland or mountain area), altitude above sea level, age of the reservoir, surface area, maximum and average depth, water level fluctuations, temperature range, descriptive biological data (abundance of vegetation and fish species composition) native or introduced, year of crayfish introduction and stocking rate (individuals/ha) of crayfish populations in Iran are given in Table I.

Anzali Lagoon is one of the most important lagoons in the Caspian Sea. It is the known place for migration to spawn, a nursery and a grow-out habitat for Caspian Sea bony fishes. It is also an important bird-nesting and wintering area (Holcik and Olah, 1992). It was suggested that the best period for crayfish harvest in Anzali Lagoon is between 6th May and 30th July. However, in August, the water temperature rises to $26^{\circ} \mathrm{C}$. Field observations showed that $26{ }^{\circ} \mathrm{C}$ is a critical temperature for Anzali Lagoon crayfish, and at $32{ }^{\circ} \mathrm{C}$ for crayfish neardeath conditions are envisaged. In this period, crayfish are reluctant, fatigued and inactive in the lagoon. Some crayfish are even found around the shallow bottom holes and under the shelters. The exotic Balanus sp. enters the lagoon by seawater penetration. They use the crayfish body as a substrate and stabilize themselves on crayfish (Karimpour et al., 1989). 
Abdolmalaki (2000) reported that there was a dramatic reduction in the number of crayfish in Anzali Lagoon in 2000. The main reasons were:

1. Caspian Sea water rose and flooded Anzali Lagoon with $12 \%$ seawater;

2. Anzali Lagoon is under the pressure of urban, industrial and agricultural pollutants;

3. Delta formation quickly decreased the depth and aquatic vegetation growth;

4. Drought;

5. Domination of eutrophic conditions and depletion of dissolved oxygen.

On the other hand, in recent years, the observations of the author showed that Anzali Lagoon seems to be in a better condition at present in comparison with the last decade.

Arass water reservoir is located in the north-west of Iran (Western Azerbaijan province). The water source of this reservoir is Arass River. It comes from Ararat Mountain between Turkey and Armenia. In 1985, Anzali Lagoon crayfish were introduced into Arass water reservoir. Because of drought between 1999 and 2001, there was a reduction in crayfish harvest in these years. The abundance of crayfish near the river and in areas near the dam is very low. Harvesting of $A$. I. eichwaldi in the Caspian Sea is not commercially viable, because catch expenses are very high and the harvest is very low. Another problem is Balanus sp. It attaches to the crayfish body. About $90 \%$ of crayfish caught on the Iranian shore of the Caspian Sea are covered by Balanus sp. After the invasion of Comb-Jelly (Mnemiopsis leidyi), this situation occurred and made the Caspian Sea crayfish unsuitable for markets, with high mortality in transportation (Nooshoori, personal communication). Its low survival rate in freshwater is another problem for exporting (Karimpour and Khanipour, 2004).

Table II shows the size composition, relationship between weight and total length, total length range, weight range, breeding season, catch season, time of first molting, sex ratio, total length range of females with pleopodal eggs, and the best period to harvest for crayfish populations in Iran.

In addition, maximum sustainable yield, catch per unit effort (1 trap in $24 \mathrm{~h}$ ), average pleopodal egg number, and average total length and weight of crayfish from different populations in Iran are given in Figures 2-5, respectively.

\section{PRODUCTION OF ASTACUS LEPTODACTYLUS IN IRAN}

All production is obtained from the wild in Iran. Crayfish have been caught commercially on a small scale in Anzali lagoon for about 80 years. In general, small round traps $(30 \mathrm{~cm}$ in diameter) with a piece of fish bait are used for crayfishing. Crayfish are not preferred by Iranian people because of religious principles. On the other hand, some people who have traveled to foreign countries or graduated from universities in European or North American countries are consumers of crayfish. Moreover, the villagers who live around Arass water reservoir have an excellent experience of the consumption of crayfish. They believe that crayfish are a very good remedy for enuresis in children.

Since the domestic consumption of crayfish is very low in Iran, crayfish production has been exported to Europe since 1985. In Iran, the main consumers of crayfish are foreign tourists visiting Anzali. In addition, some of the captured crayfish are consumed in Tehran by employees of embassies. They obtain live crayfish from local fishermen in Bandar Anzali or Arass water reservoir crayfish from fish markets in Tehran. These companies deal traditionally with the crayfish trade in Iran.

In 1985, a Turkish company (Shahlan) started to harvest crayfish from Anzali lagoon, and exported them to Turkey and European countries. It was the beginning of export of crayfish from Iran. The first harvest was $11.3 \mathrm{t}$ in 1985. There was no further crayfish harvest in Iran until 1993. In that year $3.2 \mathrm{t}$ of crayfish were exported from Iran. Today, Germany, Sweden, England and France are the main importers of crayfish from Iran. The commercial value of exported crayfish between 2000 and 2009 varied from 1.5-2.5 million US\$ annually and its amount was 106-211.5 t. On the other hand, the value of exporting the total fishery production 


\section{Table I}

Geographical information (flatland or mountain area), altitude above sea level $(m)$, age of the reservoir, surface area, maximum and average depth, water level fluctuations, temperature range in the air $\left({ }^{\circ} \mathrm{C}\right)$, descriptive biological data (abundance of vegetation and fish species composition) native or introduced, year of crayfish introduction and stocking rate (individuals $\cdot$ ha $^{-1}$ ) of crayfish populations in Iran.

\section{Tableau I}

Géographie (zones de plaine et de montagne), altitude (m), âge des réservoirs, surface et profondeur maximale et moyenne, marnage, gamme de température de l'air $\left({ }^{\circ} \mathrm{C}\right)$, données biologiques (abondance de végétation et composition spécifique des communautés piscicoles natives ou non), date des introductions d'écrevisses et taux de soutien (individus $\cdot$ ha $^{-1}$ ) des populations d'écrevisses en Iran.

\begin{tabular}{|c|c|c|c|c|c|}
\hline & Anzali Lagoon & Arass & Caspian Sea & Haft Barm Lake & Izadkhast water reservoir \\
\hline $\begin{array}{l}\text { Geographical } \\
\text { information }\end{array}$ & Flatland & Flatland & Flatland & Flatland & Mountain \\
\hline $\begin{array}{l}\text { Altitude } \\
\text { above sea } \\
\text { level }\end{array}$ & -26 & 815 & -28 & 1767 & 2142 \\
\hline $\begin{array}{l}\text { Age of the } \\
\text { reservoir }\end{array}$ & - & 40 years & - & - & 12 years \\
\hline Surface area & $150 \mathrm{~km}^{2}$ & $80-160 \mathrm{~km}^{2}$ & $371000 \mathrm{~km}^{2}$ & 80-90 ha & $50-100$ ha \\
\hline $\begin{array}{l}\text { Maximum } \\
\text { and average } \\
\text { depth }(m)\end{array}$ & $\begin{array}{l}4.0 \\
0.8\end{array}$ & $\begin{array}{l}28 \\
12\end{array}$ & $\begin{array}{c}1025 \\
187\end{array}$ & $\begin{array}{l}15 \\
12\end{array}$ & $\begin{array}{l}19 \\
9\end{array}$ \\
\hline $\begin{array}{l}\text { Water level } \\
\text { fluctuations } \\
\text { (m) }\end{array}$ & 0.2 & $3-5$ & - & 1 & 5 \\
\hline $\begin{array}{l}\text { Temperature } \\
\text { range }\left({ }^{\circ} \mathrm{C}\right)\end{array}$ & $4-30$ & $-12-31$ & $4-25$ & $4.5-28$ & $2.5-19$ \\
\hline $\begin{array}{l}\text { Descriptive } \\
\text { biological } \\
\text { data }\end{array}$ & $\begin{array}{c}12 \text { species of } \\
\text { aquatic vegetation } \\
\text { and } 42 \text { species and } \\
\text { subspecies of fish }\end{array}$ & $\begin{array}{c}\text { Potamegaton, Typha, } \\
\text { phragmetis, and } \\
15 \text { species and } \\
\text { subspecies of fish }\end{array}$ & $\begin{array}{l}115 \text { species and } \\
\text { subspecies of fish }\end{array}$ & $\begin{array}{c}\text { Potamogeton, } \\
\text { Juncus, Phragmites, } \\
\text { Polygonum, pike } \\
\text { perch, rainbow } \\
\text { trout, Chinese carp }\end{array}$ & Chinese carp \\
\hline $\begin{array}{l}\text { Native or } \\
\text { introduced }\end{array}$ & Native & Introduced & Native & Introduced & Introduced \\
\hline $\begin{array}{l}\text { Year of } \\
\text { crayfish } \\
\text { introduction }\end{array}$ & - & 1988 & - & 2001 & $2000-2001$ \\
\hline $\begin{array}{l}\text { Stocking } \\
\text { rate of } \\
\text { introduction }\end{array}$ & - & 1.25 & - & 5.55 & 70 \\
\hline
\end{tabular}

of Iran between 2000 and 2007 was 55.5-60.6 million US\$ with an amount of 9233-33 $397 \mathrm{t}$ (Anonymous, 2008). Thus, the crayfish export value and amounts are $3.45 \%$ and $0.97 \%$, respectively.

Although there have been fluctuations between years, the export of crayfish in Iran increased remarkably after 1996. Exports reached $84.7 \mathrm{t}$ in 1999 from $32.5 \mathrm{t}$ in 1998. After 2000, crayfish export was over $100 \mathrm{t}$ per year. Figure 6 shows the export values of crayfish from Iran between 1985 and 2009. In addition to these exports, the consumption of $A$. leptodactylus in Iran is approximately $1 \mathrm{t}$ annually (fisherman and dealer - personal communication).

\section{DISCUSSION AND CONCLUSION}

It can be stated that the introductions of native crayfish species, $A$. leptodactylus, into Iranian "new" freshwaters could be assumed to be successful in general. A. leptodactylus has been mating, breeding, molting and growing in their new habitats and so set up stable populations. 
Table I

Continued.

Tableau

Suite.

\begin{tabular}{|c|c|c|c|c|c|}
\hline & Khamiran & Malek Kian & Shahid Yaghoobi & Yam water & Shoorabil Lake \\
\hline $\begin{array}{l}\text { Geographical } \\
\text { information }\end{array}$ & Flatland & Mountain & Flatland & Flatland & Flatland \\
\hline $\begin{array}{l}\text { Altitude } \\
\text { above sea } \\
\text { level }(\mathrm{m})\end{array}$ & 1799 & 2142 & 1333 & 1485 & 1317 \\
\hline $\begin{array}{l}\text { Age of the } \\
\text { reservoir }\end{array}$ & 18 years & 13 years & 15 years & 12 years & - \\
\hline Surface area & 40-100 ha & $60-110$ ha & $50-180$ ha & 20-60 ha & 145-190 ha \\
\hline $\begin{array}{l}\text { Maximum } \\
\text { and average } \\
\text { depth }\end{array}$ & $\begin{array}{c}17 \\
8\end{array}$ & $\begin{array}{c}12 \\
7\end{array}$ & $\begin{array}{c}14 \\
8\end{array}$ & $\begin{array}{c}12 \\
6\end{array}$ & $\begin{array}{l}7 \\
5\end{array}$ \\
\hline $\begin{array}{l}\text { Water level } \\
\text { fluctuations }(\mathrm{m})\end{array}$ & 3 & 1.5 & 5 & 7 & 1 \\
\hline $\begin{array}{l}\text { Temperature } \\
\text { range }\left({ }^{\circ} \mathrm{C}\right)\end{array}$ & $-2-26$ & $6-23$ & $3-30$ & $4-30$ & $-4-25$ \\
\hline $\begin{array}{l}\text { Descriptive } \\
\text { biological } \\
\text { data }\end{array}$ & $\begin{array}{c}\text { Chinese carp, does } \\
\text { not have aquatic } \\
\text { vegetation }\end{array}$ & $\begin{array}{l}\text { Myriophylum, } \\
\text { Typha, Chinese } \\
\text { carp, Capoeta }\end{array}$ & $\begin{array}{l}\text { Myriophylum, } \\
\text { Potamegaton, } \\
\text { Chinese carp }\end{array}$ & $\begin{array}{c}\text { Rainbow trout, } \\
\text { Chinese carp, does } \\
\text { not have aquatic } \\
\text { vegetation }\end{array}$ & $\begin{array}{c}\text { Chinese carp, } \\
\text { Capoeta, Juncus, } \\
\text { Typha }\end{array}$ \\
\hline $\begin{array}{l}\text { Native or } \\
\text { introduced }\end{array}$ & Introduced & Introduced & Introduced & Introduced & Introduced \\
\hline $\begin{array}{l}\text { Year of } \\
\text { crayfish } \\
\text { introduction }\end{array}$ & 2001 & 2000-2001 & 2001 & 2002 & 2000-2003 \\
\hline $\begin{array}{l}\text { Stocking rate } \\
\text { of introduction }\end{array}$ & 35 & 307 & 20 & 25 & 75 \\
\hline
\end{tabular}

In addition, it seems that their growth rate in some introduced populations is better than in their original habitat. "For example, 20000 crayfish (400 kg in weight) were introduced into Arass water reservoir; these crayfish created an excellent population with an annual harvest of 100-210 t. The rate of annual crayfish harvest from the other Iranian water bodies was lower than from Arass water reservoir."

The biggest individual of $A$. leptodactylus on the north coast of the Caspian Sea was reported as $172 \mathrm{~mm}$ in total length and $180 \mathrm{~g}$ in weight by Kolmykov (2002) and as $190 \mathrm{~mm}$ and $150 \mathrm{~g}$ by Rumyanetsev (1989). On the Iranian coast of the Caspian Sea these values were $169 \mathrm{~mm}$ and $148 \mathrm{~g}$, respectively (Karimpour and Taghavi, 2002). On the other hand, the maximum of total length was $150 \mathrm{~mm}$ for the Lake Eğirdir population in Turkey (Balık et al., 2005), $155 \mathrm{~mm}$ for a population in Belarus (Alekhnovich et al., 1999), 155 and $145 \mathrm{~mm}$ for Anzali Lagoon (Abassi, 1969; Karimpour et al., 1989), 186 mm for Arass water reservoir (Karimpour and Hosseinpour, 1999), and $196 \mathrm{~mm}$ for Shoorabil lake (Abdolmalaki, 2007). That for the Haft Barm, Izadkhast, Khamiran, Malek Kian, Shahid Yaghoobiand and Yam water bodies was 166, 177, 155, 176, 156 and 163 mm, respectively (Karimpour, 2009). These comparisons could be interpreted as a strong suggestion that Iranian freshwaters offer suitable habitats for A. leptodactylus to build up very well-adapted populations.

The sex ratio of freshwater crayfish in different populations is approximately $1: 1$ in general (Cobb and Wang, 1985). However, deviations from this ratio are probably the result of seasonal and behavioral differences in male and female crayfish (Westin and Gydemo, 1988). On the other hand, Kolmykov (2001) reported that females dominated among small-sized crayfish and the proportion of males increased with size. Lewis (1998) stated that domination of males in the breeding season would suggest that females are more reclusive just prior to and during hatching of their eggs. Just after eggs hatched, females dominated the catch, 


\section{Table II}

Size composition, relationship between weight and total length, total length range, weight range, breeding season (including the mating, egg-laying and hatching periods), catch season, time of first moltings, sex ratio, total length range of females with pleopodal eggs, and the best period to harvest for crayfish populations in Iran.

\section{Tableau II}

Composition en taille, relation entre poids et longueur totale, gamme de longueur et de poids, saison de reproduction (accouplement, incubation des œufs et période d'éclosion), saison de pêche, date des première mues, sexe ratio, gamme des longueurs des femelles incubant, période des meilleures captures en Iran.

\begin{tabular}{|c|c|c|c|c|c|}
\hline & Anzali Lagoon & Arass & Caspian Sea & Haft Barm Lake & Izadkhast water reservoir \\
\hline $\begin{array}{l}\text { Size } \\
\text { composition } \\
\text { (grams in } \\
\text { percentage) }\end{array}$ & & & & & \\
\hline$>200$ & - & 5.38 & - & - & - \\
\hline 100-200 & 1 & 16.82 & 2.8 & 6.94 & 6.44 \\
\hline 70-100 & 8 & 19.07 & 37.48 & 21.63 & 23.79 \\
\hline $50-70$ & 22 & 41.91 & 28.66 & 40.61 & 19.68 \\
\hline $30-50$ & 26 & 11.15 & 19.02 & 17.76 & 36.86 \\
\hline$<30$ & 43 & 5.67 & 12.04 & 13.06 & 13.23 \\
\hline $\begin{array}{l}\text { Relationship } \\
\text { between } \\
\text { weight }(\mathrm{g}) \text { and } \\
\text { total length }\end{array}$ & Data not available I & O & 0 00001129 T 3.2280 & I 3.451 & 0000005 Tl 3.402 \\
\hline For females & Data not available & $0.0000794 \mathrm{TL}^{3.0843}$ & $0.00008794 \mathrm{TL}^{2.7374}$ & $0.0000319 \mathrm{TL}^{2.953}$ & $0.00005 \mathrm{TL}^{2.865}$ \\
\hline For both sexes & Data not available & $0.00000523 \mathrm{TL}^{3.3581}$ & $0.0001219 \mathrm{TL}^{2.7041}$ & $0.00000237 \mathrm{TL}^{3.535}$ & $0.000004 \mathrm{TL}^{3.430}$ \\
\hline $\begin{array}{l}\text { Total length } \\
\text { range }(\mathrm{mm})\end{array}$ & $72-145$ & $78-186$ & $72-169$ & $82-166$ & $75-177$ \\
\hline $\begin{array}{l}\text { Weight } \\
\text { range (g) }\end{array}$ & Data not available & $12.3-239.6$ & $12.5-148$ & $21-182$ & $12.6-192.3$ \\
\hline $\begin{array}{l}\text { Breeding } \\
\text { season }\end{array}$ & 15th Nov.-1st May & 11th Dec.-30th May & 21st Nov.-22nd July & 21st Nov.-21st May & 15th Nov.-30th May \\
\hline Catch season & 6th May-6th Nov. & 6th Jun.-6th Dec. & 20th Jul.-20th Jan. & 1st Jun.-15th Nov. & 5th Jun.-10th Nov. \\
\hline $\begin{array}{l}\text { First moltings } \\
\text { occur }\end{array}$ & 1st-20th Apr. & 20th Apr.-10th May & 1st-30th July & 10th-30th Apr. & 10th May-10th Jun. \\
\hline $\begin{array}{l}\text { Sex ratio in } \\
\text { whole of the } \\
\text { year (female: } \\
\text { male) }\end{array}$ & $\begin{array}{c}1: 1.17 \\
(n=22198)\end{array}$ & $\begin{array}{c}1: 1.33 \\
(n=71127)\end{array}$ & $\begin{array}{c}1: 0.86 \\
(n=5867)\end{array}$ & $\begin{array}{c}1: 1.31 \\
(n=11342)\end{array}$ & $\begin{array}{c}1: 1.17 \\
(n=11171)\end{array}$ \\
\hline $\begin{array}{l}\text { Range of TL of } \\
\text { females with } \\
\text { pleopodal } \\
\text { eggs }(\mathrm{mm})\end{array}$ & $84-121$ & $81-153$ & 103-152 & $92-142$ & $86-137$ \\
\hline $\begin{array}{l}\text { Best period } \\
\text { to harvest }\end{array}$ & 6th May-30th Jul. & 1st Jul.-31st Oct. & $\begin{array}{c}\text { Harvest is not } \\
\text { economically viable }\end{array}$ & 15th Jun.-1st Nov. & 15th Jun.-1st Nov. \\
\hline References & $\begin{array}{c}\text { Karimpour et al. } \\
(1989,1991)\end{array}$ & $\begin{array}{c}\text { Karimpour and } \\
\text { Hosseinpour (1999), } \\
\text { Karimpour and } \\
\text { Taghavi (2003) }\end{array}$ & $\begin{array}{l}\text { Karimpour and } \\
\text { Taghavi (2002) }\end{array}$ & Karimpour (2009) & Karimpour (2009) \\
\hline
\end{tabular}

suggesting that they were aggressively seeking food to replenish reserves lost during the hatching period.

Furthermore, some authors studied the effects of shape and kind of trap on the sex ratio in the crayfish catch (Collins et al., 1983; Fjalling, 1995). For example, some traps caught more male freshwater crayfish Astacus astacus (Abrahamsson, 1966); this has also been proved by Brown and Brewis (1979) for Austropotamobius pallipes, by Skurdal et al. (1995) for $A$. astacus, by Frutiger et al. (1999) for Procambarus clarki, by Karimpour et al. (2003) for A. leptodactylus, and by Campbell and Whisson (2000) for Cherax tenuimanus. 


\section{Table II}

Continued.

Tableau II

Suite.

\begin{tabular}{|c|c|c|c|c|c|}
\hline & Khamiran & Malek Kian. & Shahid Yaghoobi & Yam water & Shoorabil Lake \\
\hline \multicolumn{6}{|l|}{$\begin{array}{l}\text { Size } \\
\text { composition } \\
\text { (grams in } \\
\text { percentage) }\end{array}$} \\
\hline$>200$ & - & - & - & - & 5.41 \\
\hline $100-200$ & 6.76 & 11.51 & 4.42 & 8.64 & 19.40 \\
\hline 70-100 & 13.17 & 45.37 & 12.54 & 29.63 & 26.98 \\
\hline $50-70$ & 34.21 & 27.15 & 22.90 & 24.99 & 29.18 \\
\hline $30-50$ & 42.66 & 11.50 & 44.12 & 20.69 & 13.87 \\
\hline$<30$ & 3.20 & 4.47 & 16.02 & 16.05 & 5.16 \\
\hline \multicolumn{6}{|l|}{$\begin{array}{l}\text { Relationship } \\
\text { between weight } \\
\text { (g) and total } \\
\text { length }(\mathrm{mm})\end{array}$} \\
\hline For males & $0.0000116 \mathrm{TL}^{3.222}$ & $0.000005 \mathrm{TL}^{3.395}$ & $0.00003 \mathrm{TL}^{3.033}$ & $0.000007 \mathrm{TL}^{3.351}$ & $0.00005 \mathrm{TL}^{2.944}$ \\
\hline For females & $0.0000149 \mathrm{TL}^{3.139}$ & $0.00005 \mathrm{TL}^{2.888}$ & $0.0001 \mathrm{TL}^{2.664}$ & $0.00006 \mathrm{TL}^{2.853}$ & $0.000006 \mathrm{TL}^{3.676}$ \\
\hline For both sexes & $0.00000840 \mathrm{TL}^{3.279}$ & $0.00000 \mathrm{TL}^{3.359}$ & $0.00003 T^{2.964}$ & $0.000006 \mathrm{TL}^{3.345}$ & $0.0000036 T^{3.452}$ \\
\hline $\begin{array}{l}\text { Total length } \\
\text { range }(\mathrm{mm})\end{array}$ & $93-155$ & $85-176$ & $78-156$ & $76-163$ & $34-196$ \\
\hline $\begin{array}{l}\text { Weight (g) } \\
\text { range }\end{array}$ & $22-147$ & $19.1-199.7$ & $15.7-141.6$ & $12.6-172.6$ & $9.6-328$ \\
\hline $\begin{array}{l}\text { Breeding } \\
\text { season }\end{array}$ & 1st Nov.-15th May & 10th Nov.-1st Jun. & 21st Nov.-1st Jun. & 21st Nov.-1st Jun. & 5th Dec.-20th Jun. \\
\hline Catch season & 20th May-20th Oct. & 5th Jun.-5th Nov. & 10th Jun.-15th Nov. & 10th Jun.-15th Nov. & 1st Jul.-1st Dec. \\
\hline $\begin{array}{l}\text { First moltings } \\
\text { occur }\end{array}$ & 20th May-10th Jun. & 10th-31st May & 10th-31st May & 10th-31st May & 5th May-5th Jun. \\
\hline $\begin{array}{l}\text { Sex ratio in } \\
\text { whole of the } \\
\text { year (female: } \\
\text { male) }\end{array}$ & $\begin{array}{c}1: 1.22 \\
(n=13432)\end{array}$ & $\begin{array}{c}1: 1.01 \\
(n=5075)\end{array}$ & $\begin{array}{c}1: 0.97 \\
(n=11435)\end{array}$ & $\begin{array}{c}1: 1.25 \\
(n=2409)\end{array}$ & $\begin{array}{c}1: 2.45 \\
(n=7144)\end{array}$ \\
\hline $\begin{array}{l}\text { Range of TL } \\
\text { of females with } \\
\text { pleopodal eggs }\end{array}$ & $\begin{array}{l}98-143 \\
(n=73)\end{array}$ & $\begin{array}{c}102-155 \\
(n=79)\end{array}$ & $\begin{array}{l}95-135 \\
(n=53)\end{array}$ & $\begin{array}{l}91-152 \\
(n=56)\end{array}$ & $\begin{array}{c}103-140 \\
(n=35)\end{array}$ \\
\hline $\begin{array}{l}\text { Best period } \\
\text { to harvest }\end{array}$ & 1st Jun.-10th Oct. & 15th Jun.-31st Oct. & 15th Jun.-31st Oct. & 15th Jun.-31st Oct. & 15th Jul.-30th Nov \\
\hline References & Karimpour (2009) & Karimpour (2009) & Karimpour (2009) & Karimpour (2009) & Abdolmalaki (2007) \\
\hline
\end{tabular}

The sex ratio in the whole of year was found to be 1:1 for the Mogan Lake population of A. leptodactylus in Turkey by Bayrak (1985), for the population of the Caspian Sea coast of Turkmenistan by Rumyanetsev (1989), for the population of the Lake Ageri in Switzerland by Stucki (1999), for the population of the north coast of the Caspian Sea by Kolmykov (2001) and for the population of Belarus water bodies by Alekhnovich and Kulesh (1996). With the exception of Caspian Sea crayfish on the Iranian coast with a sex ratio of 1:0.86 (female:male) (Karimpour and Taghavi, 2002) and Shoorabil Lake crayfish with a sex ratio of 1:2.45 (Abdolmalaki, 2007), for other Iranian water bodies the sex ratio is close to 1:1.

Mature females of the Caspian Sea A. leptodactylus have a minimum length of $7-8 \mathrm{~cm}$ in total length (TL) which corresponds to the age of two years; mature females account for $7-8 \%$ of this size group (Kolmykov, 2002). Eighty-six-94\% of the females over $8 \mathrm{~cm}$ in TL have pleopodal eggs (Rumyanetsev, 1989). The smallest females with pleopodal eggs were between 75 and $85 \mathrm{~mm}$ TL for different water bodies of Belarus (Alekhnovich and Kulesh, 1996), $79 \mathrm{~mm}$ for the Karelia region of Russia (Alexandrov, 1968), 98 mm for Lake Eğirdir of Turkey (Balık 


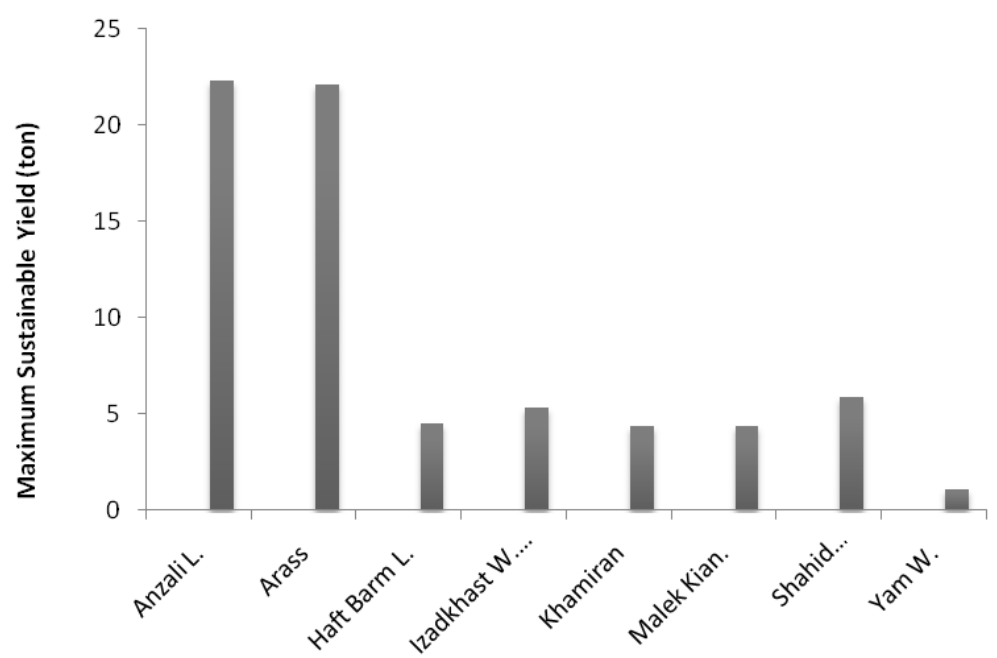

\section{Figure 2}

Maximum sustainable yield of crayfish populations in Iran.

\section{Figure 2}

Rendement maximum soutenu des populations d'écrevisses en Iran.

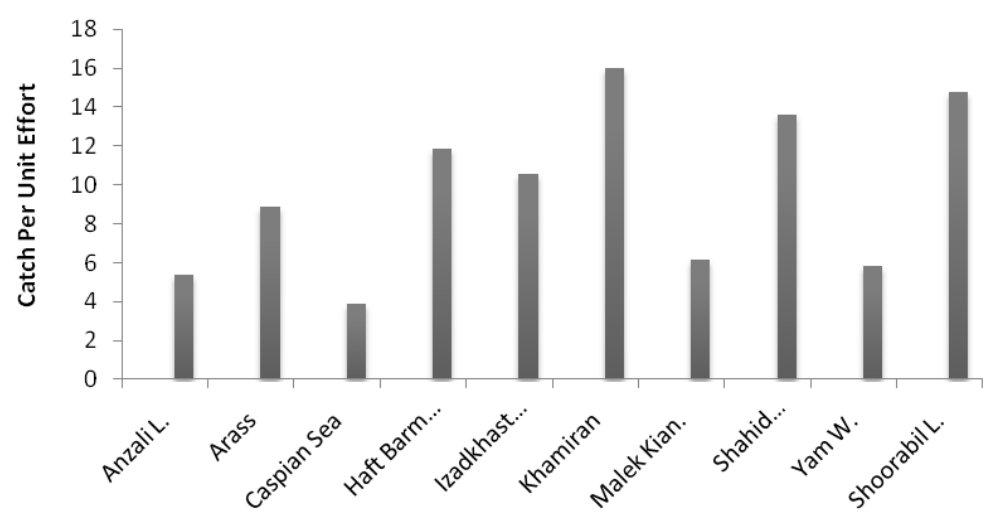

Figure 3

Catch per unit effort (1 trap in 24 h) of crayfish populations in Iran.

\section{Figure 3}

Captures par unité d'effort (1 trappe en 24 h) dans les populations d'écrevisses en Iran.

et al., 2005), $92 \mathrm{~mm}$ for Lake Ageri of Switzerland (Stucki, 1999), $85 \mathrm{~mm}$ for the delta of the Volga River (Nefedov, 1974), $75 \mathrm{~mm}$ for the Caspian Sea coast of Turkmenistan (Cherkashina, 1975), $74 \mathrm{~mm}$ for the middle of the Volga River (Suprunovich, 1976), $70 \mathrm{~mm}$ for the Don River (Shpolyanskaya, 1980), $103 \mathrm{~mm}$ for the Iranian coast of the Caspian Sea (Karimpour and Taghavi, 2002), $87 \mathrm{~mm}$ for the Arass water reservoir (Karimpour and Hosseinpour, 1999), and $92 \mathrm{~mm}$ for Anzali Lagoon (Karimpour et al., 1989). TL of crayfish caught in Iranian inland water bodies was between 86 and 103 mm (Abdolmalaki, 2007; Karimpour, 2009).

One of the most important characteristics of $A$. leptodactylus is its high fecundity. An increase in size causes an increase in fecundity in A. leptodactylus. The correlation coefficient between these two factors is usually more than $85 \%$. The average number of pleopodal eggs was 209 for A. leptodactylus caught in Lake Eğirdir (Balık et al., 2005), 306 for Keban Dam Lake (Harlıoglu et al., 2004), 196 for the north Caspian Sea, 361 for the Volga River (Kolmykov, 2002), 221 for Anzali Lagoon (Karimpour et al., 1989), and 255 for the Iranian coast of the 


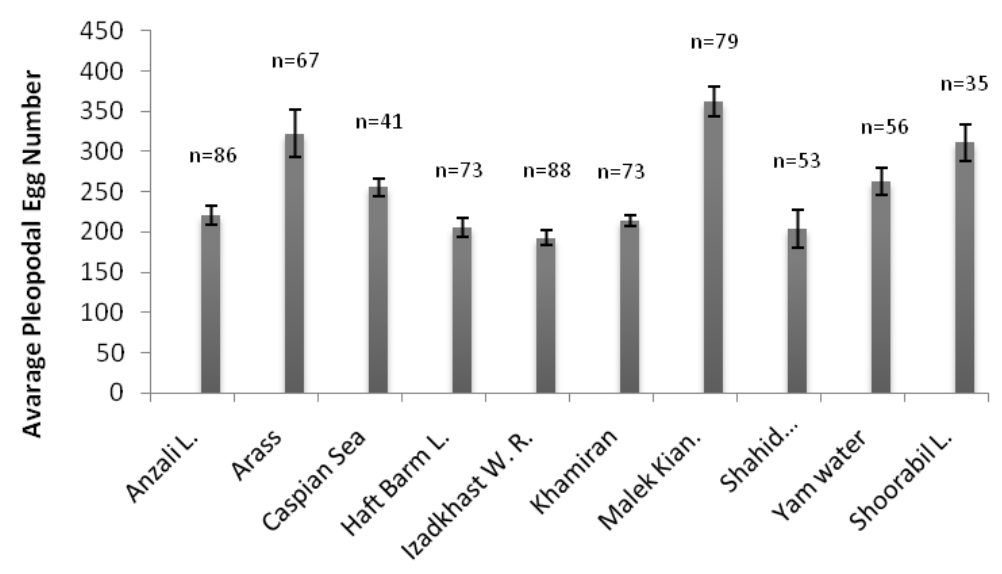

\section{Figure 4}

Average pleopodal egg number (with standard deviation) of crayfish from different populations in Iran.

Figure 4

Nombre moyen d'œufs (avec déviation standard) par écrevisse de différentes populations en Iran.

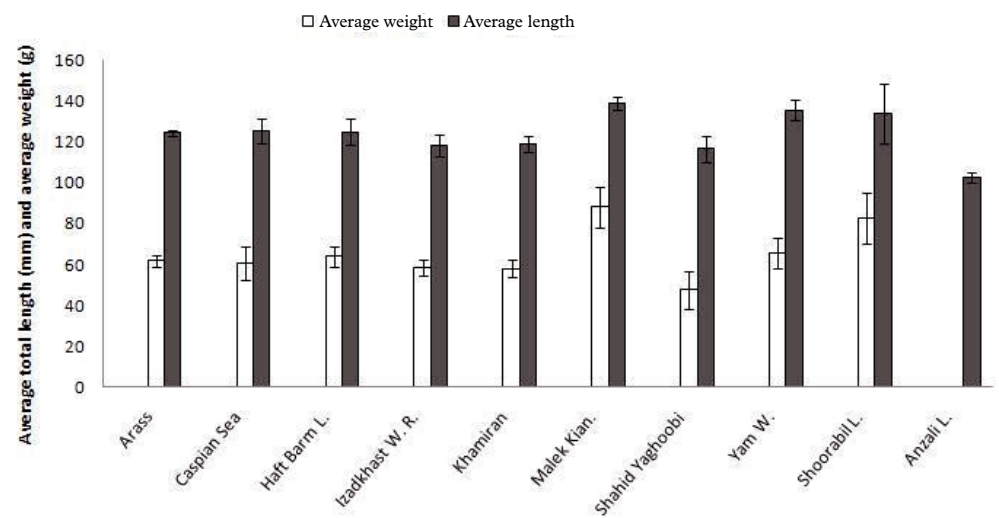

Figure 5

Average total length and weight (with standard deviation) of crayfish from different populations in Iran.

Figure 5

Longueur totale et poids moyens (avec déviation standard) des écrevisses de différentes populations en Iran.

Caspian Sea (Karimpour and Taghavi, 2002). That of $A$. leptodactylus caught from the Iranian inland water bodies was 193 for Izadkhast, and 362 for Malek Kian.

The average pleopodal egg number of $A$. leptodactylus caught in Arass water reservoir (the original habitat of introduced crayfish) was 322 . However, while that of $A$. leptodactylus caught in Haft Barm, Izadkhast, Khamiran and Shahid Yaghoobi water resources was less than Arass water reservoir, A. leptodactylus caught from Malek Kian, Yam and Shoorabil had a higher average pleopodal egg number than Arass (Table I).

The present study shows that the average length and weight of $A$. leptodactylus in most introduced populations in Iran are greater than other populations of this species in other areas. In addition, the majority of $A$. leptodactylus populations in Iran have large-sized crayfish (bigger than $70 \mathrm{~g}$ ) in comparison with other populations. Furthermore, the fecundity of A. leptodactylus populations in Iran is close to other populations of this species and the sex ratio is approximately 1:1 except for Shoorabil Lake.

A. leptodactylus is a cold water species like other European crayfish; the length of its reproduction cycle varies according to the climate of the habitat in which it lives (Köksal, 1988). 


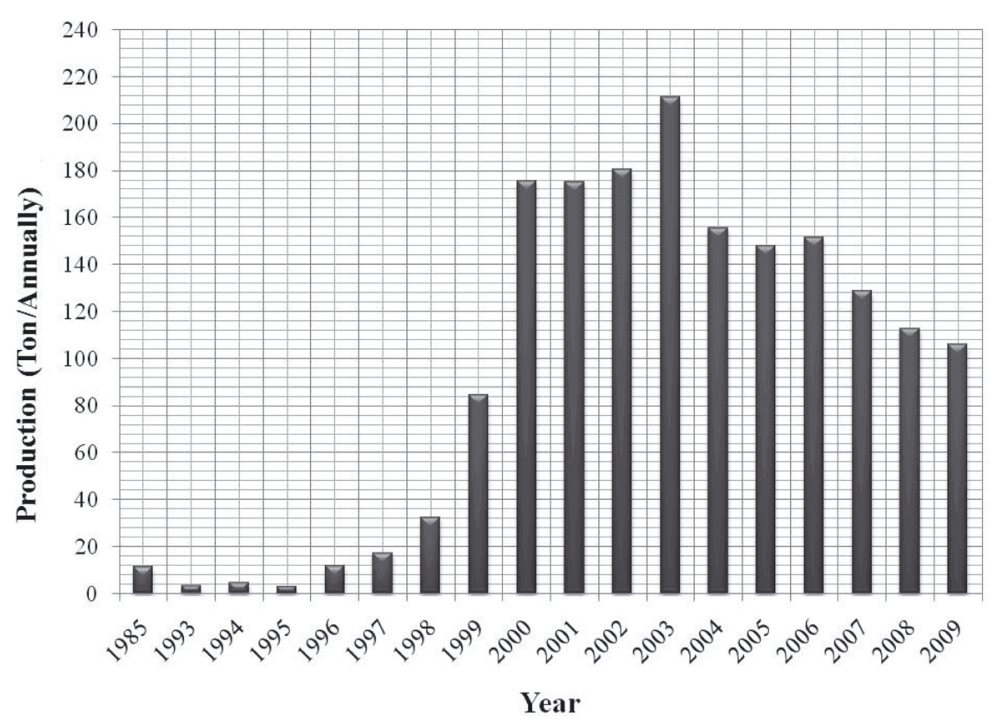

Figure 6

The export values (t/a) of crayfish from Iran between 1985 and 2009.

Figure 6

Exportations (t/a) d'écrevisses d'Iran entre 1985 et 2009.

The mating of $A$. leptodactylus occurs at below $12^{\circ} \mathrm{C}$ and after $2-4$ weeks with a temperature of $6-11^{\circ} \mathrm{C}$ the pleopodal eggs appear; the hatching begins at $18^{\circ} \mathrm{C}$ and at $20-21^{\circ} \mathrm{C}$ juveniles detach from the mother (Groves, 1985). On the Turkmenistan coast of the Caspian Sea the appearance of pleopodal eggs happened at $9-11^{\circ} \mathrm{C}$ and juveniles were released at $21-23^{\circ} \mathrm{C}$ (Cherkashina, 1975). In the Lake District in Turkey mating occurred in November at $7-8{ }^{\circ} \mathrm{C}$ and egg-laying began in early December at $4-7^{\circ} \mathrm{C}$, the eggs hatched in late May when the water temperature was $21-23^{\circ} \mathrm{C}$ and it lasted until the third week of June (Köksal, 1988). In another population, in the Don River, hatching occurred in the third week of May to mid-June (Cherkashina, 1977). On the Iranian coast of the Caspian Sea the breeding season (including the mating egg-laying and hatching periods) happens between 21st January and 22nd July in general (Karimpour and Taghavi, 2002). In the other Iranian water bodies it starts on the first of November and finishes on the 20th of June. For this reason, crayfish catch was forbidden by the Iranian government from the first of January to the middle of July in the North of the Caspian Sea (Kolmykov, 2002). On the coast of the Caspian Sea of Turkmenistan the crayfish catch period is between June and December (Rumyanetsev, 1989). On the Iranian coast of the Caspian Sea crayfish catching is allowed between 20th July and 20th January (Karimpour and Taghavi, 2002). In the freshwater lakes and reservoirs in Iran the crayfish season is determined to be between 15th May and 15th December. The harvest of freshwater crayfish A. leptodactylus in Turkey starts on 15th June and ends on December 24th (Harlıoğlu and Harlıoğlu, 2004).

CPUE depends on the crayfish population density, and also on the population structure, and these two are dependent on the habitat. For example, it was observed that the CPUE of the Iranian coast of the Caspian Sea crayfish depended on the sediment type, particle size and nutrients in the sediment (Karimpour, unpublished data). In addition, observations of Iranian inland water bodies showed that in the lakes or water reservoirs with aquatic vegetation in shallow water CPUE was higher than the area without aquatic plants. As a result of these observations, Iranian crayfish populations can be categorized as below:

Excellent stock: CPUE $>15$,

Very good stock: CPUE $=10-15$,

Good stock: CPUE $=5-10$,

Medium stock: CPUE $<5$. 
On the basis of this categorization, it can be concluded that Khamiran water reservoir has the most excellent crayfish stock in Iran. Haft Barm, Izadkhast, Shahid Yaghoobi and Shoorabil have very good stock, and Anzali Lagoon, Arass, Malek Kian and Yam water reservoirs have good stocks. On the other hand, the Caspian Sea has a medium crayfish stock.

There are about 300 people employed in fishing, packaging and exporting of crayfish in Iran at present. To increase crayfish production in Iran different projects in crayfish aquaculture should be fulfilled, but aquaculture is not preferred in Iran because of the fact that obtaining crayfish from aquaculture is more expensive than harvesting crayfish from freshwater resources.

The findings of the present study show that Iranian freshwater bodies offer suitable habitats for $A$. leptodactylus self-sustaining populations. Therefore, it can be concluded that to increase crayfish production in Iran introduction of $A$. leptodactylus should be continued into suitable water resources under controlled conditions. In addition to this, the potential impact of "new" A. leptodactylus populations on the biodiversity of water ecosystems, and management, conservation and monitoring of crayfish populations should be carried out.

\section{ACKNOWLEDGEMENTS}

Thanks to Dr. D. Holdich for his help with preparing the references for the corresponding author.

\section{REFERENCES}

Abassi H., 1969. Length frequency of Anzali Lagoon freshwater crayfish (Astacus leptodactylus), Iranian Fisheries Research Institute, Bandar Anzali, $7 \mathrm{p}$.

Abdolmalaki S., 2000. Anzali Lagoon freshwater crayfish Astacus leptodactylus stock assessment, Caspian Sea Bony Fishes Research Center, Bandar Anzali, 71 p.

Abdolmalaki S., 2007. Shoorabil Lake freshwater crayfish Astacus leptodactylus stock assessment, Inland Water Aquaculture Institute, Bandar Anzali, 69 p.

Abrahamsson S.A.A., 1966. Dynamics of an isolated population of the crayfish Astacus astacus. Oikos, 2, 111-126.

Alekhnovich A. and Kulesh V., 1996. Comparative analysis of reproduction of narrow-clawed crayfish Astacus leptodactylus in its eastern area. Freshw. Crayfish, 11, 339-347.

Alekhnovich A., Kulesh V. and Ablov S., 1999. Growth and size structure of narrow-clawed crayfish Astacus leptodactylus in its easter area. Freshw. Crayfish, 12, 550-562.

Alexandrov B.M., 1968. On crayfish Astacus leptodactylus in Karelia, Transactions of Karelian Section of Caspian Sea Fisheries Research Institute, Astrakhan, $21 \mathrm{p}$.

Anonymous, 2008. Annual Iranian fisheries statistics, Fisheries Design and Program Office, $62 \mathrm{p}$.

Balık I., Cubuk H., Ozkok R. and Uysal R., 2005. Some biological characteristics of freshwater crayfish Astacus leptodactylus in Lake Eğirdir. Tr. J. Zool., 29, 295-300.

Bayrak M., 1985. Research on fecundity and growth of freshwater crayfish Astacus leptodactylus in Mogan Lake, Ph.D. thesis, Ankara University, Turkey.

Brown D.J. and Brewis J.M., 1979. A critical look at trapping as a method of sampling a population of Austropotamobius in mark and recapture study. Freshw. Crayfish, 4, 159-164.

Butcher T., 1971. Anzali lagoon freshwater crayfish Astacus leptodactylus project, Preliminary report, Iranian Fisheries Research Institute, Bandar Anzali, 5 p.

Campbel L. and Whisson G.J., 2000. Catch efficiency of five freshwater crayfish traps in south-west, Western Australia. Freshw. Crayfish, 13, 58-67.

Cherkashina N.Y., 1975. Distribution and biology of genus Astacus in Turkmen waters of the Caspian Sea. Freshw. Crayfish, 2, 553-555.

Cherkashina N.Y., 1977. Survival, growth and feeding dynamics of juveniles crayfish Astacus leptodactylus in pond and River Don. Freshw. Crayfish, 3, 95-100. 
Cobb J.S. and Wang D., 1985. Fisheries Biology of Lobsters and Crayfish, The Biology of Crustacean, 10, Academic Press, New York, 206-208.

Collins N.C., Harvey H.H., Tieray A.J. and Dunham D.W., 1983. Influence of predatory fish density on trap ability of crayfish in Ontario Lake. Can. J. Fish. Aqu. Sci., 40, 1820-1841.

Fjalling A., 1995. Crayfish traps in Swedish fisheries. Freshw. Crayfish, 8, 201-14.

Frutiger A., Borner S., Busset T., Eggen R., Muller S. and Wasmer H.R., 1999. How to control unwanted population of Procambarus clarkii in central Europe. Freshw. Crayfish, 12, 714-725.

Ghoolami N., 2002. The effects of pesticides and herbicides on freshwater crayfish (Astacus leptodactylus) juveniles mortality, MSc. thesis, Azad Universiy of Gilan (in Persian).

Groves R.E., 1985. Crayfish: Its Nature and Nurture, Fishing News Books Ltd, Farnham, 72 p.

Harlığlu M.M. and Harlığlu A.G., 2004. The harvest of freshwater crayfish Astacus leptodactylus in Turkey. Rev. Fish Biol. Fish., 14, 415-419.

Harlıoğlu M.M., Barim O., Turkgulu I. and Harlıoğlu A.G., 2004. Potential fecundity of an introduced population, Keban Dam Lake, Elazig, Turkey of freshwater crayfish Astacus leptodactylus. Aquacult., 230, 189-195.

Holcik J. and Olah J., 1992. Fish, fisheries and water quality in Anzali Lagoon and its watershed, Field Document 2, UNDP/IRA/001, FAO, Rome, $109 \mathrm{p}$.

Karimpour M., 2009. Some biological survey and determination of MSY of freshwater crayfish Astacus leptodactylus in six crayfish introduced inland water, Iranian Fisheries Organization, Aquaculture Management, Tehran, $361 \mathrm{p}$.

Karimpour M. and Hosseinpour S.N., 1999. Population dynamism and determination of MSY of Arass water reservoir freshwater crayfish Astacus leptodactylus, Caspian Sea Bony Fishes Research Center, Bandar Anzali, 186 p.

Karimpour M. and Khanipour A.A., 2004. The effect of different salinities and freshwater on the survival rate of the Caspian Sea crayfish Astacus leptodactylus eichwald, Caspian Sea Bony Fishes Research Center, Bandar Anzali, 73 p.

Karimpour M. and Taghavi S.A., 2002. The research on biological characteristics, density of distribution and test for best kind traps to fish Caspian Sea crayfish Astacus leptodactylus eichwaldii, Caspian Sea Bony Fishes Research Center, Bandar Anzali, 163 p.

Karimpour M. and Taghavi S.A., 2003. Arass water reservoir crayfish Astacus leptodactylus monitoring stock, Caspian Sea Bony Fishes Research Center, Bandar Anzali, 82 p.

Karimpour M., Hosseinpour S.N. and Haghighi D., 1989. Anzali Lagoon freshwater crayfish Astacus leptodactylus biological survey, Gillan Fisheries Research Center, Bandar Anzali, 57 p.

Karimpour M., Hosseinpour S.N. and Haghighi D., 1991. Anzali Lagoon freshwater crayfish Astacus leptodactylus stock assessment and determination of MSY, Gillan Fisheries Research Center, Bandar Anzali, $36 \mathrm{p}$.

Karimpour M., Taghavi S.A. and Khanipour A.A., 2003. Comparative study of Opera House Traps and Funnel Traps for catching Freshwater crayfish Astacus leptodactylus in the Arass water reservoir, Caspian Sea Bony Fishes Research Center, Bandar Anzali, 73 p.

Köksal G., 1988. Astacus leptodactylus in Europe. In: Holdich D.M. and Lowery R.S. (eds.), Freshwater Crayfish: Biology, Management and Exploitation, Chapman and Hall, London, 365-400.

Kolmykov E.B., 2001. Biological principles of regulation of crayfish (Pontastacus) abundance in the Volga River delta, Caspian Sea Fisheries Research Institute, Astrakhan, 24 p.

Kolmykov E.B., 2002. Pontastacus eichwaldi Bott, 1950, Caspian Sea Fisheries Research Institute, Astrakhan, $8 \mathrm{p}$.

Lewis S.D., 1998. Life history, population dynamics and management of signal crayfish Pacifastacus leniusculus in Lake Billy Chinock, Oregon State University, 98 p.

Nefedov V.N., 1974. Reproduction of narrow-clawed crayfish Astacus leptodactylus in water of VolgaAkhtuba flood-lands. Transactions of Volgograd Section of Caspian Sea Fisheries Research Institute, 8, 68-79.

Petr T., 1987. Observation of prospects furthers inland fisheries development in Iran, FAO, Rome, F1, TCP/IRA/6675.

Rumyanetsev V.D., 1989. Caspian Sea Crayfish [Translated to English: Holcik J., 1990], Gilan Fisheries Research Center, Bandar Anzali, $11 \mathrm{p}$. 
Shpolyanskaya N.A., 1980. Some question of reproduction of narrow-clawed crayfish Astacus leptodactylus cubanicus in Rostov province - Biology of Inland Waters, Information Bulletin, 4, Leningrad, 68-79.

Skurdal J., Qvenild T. and Taugbol T., 1995. Size and sex composition on noble crayfish Astacus astacus in trap catches in Lake Steinfjorden, South-east Norway, effect of exploitation. Freshw. Crayfish, 8, 249-256.

Stucki T.P., 1999. Life cycle and life history of Astacus leptodactylus in Chatzensec Lake (Zurich) and Lake Ageri in Switzerland. Freshw. Crayfish, 12, 430-448.

Suprunovich V.A., 1976. Fecundity of narrow-clawed crayfish Astacus leptodactylus at Dniester estuary and peculiarities of its alteration, Abstract of Ph.D. thesis, Kiev University (in Russian).

Veladykov V.D., 1964. Inland fisheries resources of Iran especially of the Caspian Sea with special reference to Sturgeon, Report to Government of Iran, FAO Report, FAO, Rome, 188, 64 p.

Westin L. and Gydemo R., 1988. Variation in sex ratio in the noble crayfish Astacus astacus: A reflection of yearly activity change. Freshw. Crayfish, 7, 115-120. 